\title{
Aplikasi Teknologi RFID pada E-Rekam Medis untuk Manajemen Posyandu Berbasis Web
}

\author{
Tyas Aprilia ${ }^{1}$, Nugroho Suharto ${ }^{2}$, Lis Diana ${ }^{3}$ \\ ${ }^{1}$ Program Studi Jaringan Telekomunikasi Digital, Jurusan Teknik Elektro, \\ Politeknik Negeri Malang \\ ${ }^{2,3}$ Program Studi Teknik Telekomunikasi, Jurusan Teknik Elektro, \\ Politeknik Negeri Malang \\ 1tyasaprilia107@gmail.com, ${ }^{2}$ nugroho.suharto@polinema.ac.id, ${ }^{3}$ lis.diana@polinema.ac.id
}

\begin{abstract}
The current measurement process in posyandu generally done manually, i.e. when the user arrives, the measurement will be taken then the data stored manually by writing on paper. This system is considered inefficient because it's need a long time, causing long queues and the possibility of stacked data storage. From several indications of problems that have een found, it's necessary to develop a system that makes posyandu and midwives work quickly and accurately. Therefore, it's necessary to develop technology that aims to create a new system, namely the application of rfid technology to medical e-records for web-based posyandu management.

This study uses Arduino as microcontroller and raspberry pi as server, there is node, inside the node there is an ultrasonic sensor to determine height, then load cell sensor to determine the user's weight. Data will be sent from Arduino Uno to NRF, on the server there is NRF24L01, the server used is a raspberry pi 3. The client server communication technique is designed for communication between nodes and servers so that data transmission errors are smaller.

Based on the test results, it's known that RFID has maximum detection distance limit of $3 \mathrm{~cm}$ with a maximum detection delay of $2.9 \mathrm{~s}$. In the medical e-record system made, the load cell sensor has an error deviation of $3.48 \%$ and the ultrasonic sensor is $1.129 \%$. The data that can be displayed on the application includes the toddler's name, weight and height. Based on the test results, it's known that the accuracy of data communication has the best packet loss value of $0 \%$, the worst packet loss value is $0.18 \%$, the best delay value is $0.1 \mathrm{~s}$ and the worst delay value is $4.1 \mathrm{~s}$.
\end{abstract}

Keywords-Arduino, RFID, node, medical e-records, NRF24L01.

Abstrak-Proses pengukuran di posyandu saat ini umumnya dilakukan dengan cara manual yaitu ketika pengguna datang akan dilakukan pengukuran kemudian data disimpan secara manual dengan menulis di kertas. Sistem ini dinilai belum efisien karena membutuhkan waktu yang lama, sehingga menyebabkan panjangnya antrian dan kemungkinan penyimpanan data tertumpuk. Dari beberapa indikasi masalah yang telah ditemukan, diperlukan sebuah pengembangan sistem yang membuat pekerjaan petugas posyandu maupun bidan secara cepat dan akurat. Maka dari itu diperlukan pengembangan teknologi yang bertujuan menciptakan sistem baru yaitu aplikasi teknologi rfid pada e-rekam medis untuk manajemen posyandu berbasis web.

Penelitian ini menggunakan Arduino sebagai mikrokontroler dan raspberry pi sebagai server, terdapat node, di dalam node terdapat sensor ultrasonik untuk mengetahui tinggi badan, kemudian sensor load cell untuk mengetahui berat badan user. Data akan dikirim dari arduino uno ke NRF setelah itu pada server terdapat NRF24L01, server yang digunakan merupakan raspberry pi 3. Teknik komunikasi client server dirancang untuk komunikasi antara node dengan server sehingga error pengiriman data menjadi lebih kecil.

Berdasarkan hasil pengujian diketahui bahwa RFID memiliki batas jarak maksimum deteksi yaitu 3cm dengan delay maksimum deteksi sebesar 2,9s. Pada sistem e-rekam medis yang dibuat, sensor load cell memiliki deviasi error sebesar $3,48 \%$ dan sensor ultrasonik sebesar 1,129\%. Data yang dapat ditampilkan pada aplikasi meliputi nama batita, berat badan dan tinggi badan. Berdasarkan hasil pengujian diketahui keakuratan komunikasi data nilai packet loss terbaik $0 \%$, nilai packet loss terburuk $0,18 \%$, nilai delay terbaik $0,1 \mathrm{~s}$ dan nilai delay terburuk $4,1 \mathrm{~s}$.

Kata kunci- Arduino, RFID, node, e-rekam medis, NRF24L01.

\section{PENDAHULUAN}

Posyandu merupakan kegiatan pemantauan terhadap kondisi anak yang di lakukan secara rutin dan terus menerus tiap bulan. Pemantauan kesehatan anak dilakukan dengan tujuan untuk mengontrol tumbuh kembang anak agar bisa melakukan sebuah pencegahan untuk menghindari terjadinya sebuah penyakit [1]. Beberapa kendala yang muncul saat melakukan pemeriksaan yaitu laporan hasil rekam medis yang di tulis secara manual (paper base) dan berkas hasil pemeriksaan itu menumpuk dengan berkas lain yang tidak di simpan berdasarkan urutan. Sehingga sistem tersebut menyulitkan petugas administrasi saat melakukan pencarian suatu data.

Kemajuan IPTEK (ilmu pengetahuan dan teknologi) yang semakin pesat tidak dapat dipungkiri bahwa inovasi berbagai penelitian semakin berkembang pesat. Kemajuan IPTEK telah banyak digunakan dalam berbagai aktivitas manusia, salah satunya bidang kesehatan yaitu membantu pelayanan dalam bidang pemeriksaan kesehatan. Manusia sendirilah yang menjadi subyek utama faktor IPTEK dikembangkan. Indonesia masih menjadi negara konsumen untuk perkembangan alat-alat modern dibidang IPTEK, karena 
produktifitasnya masih rendah. Seharusnya Indonesia mampu menciptakan alat-alat yang dapat memiliki nilai jual. Sehingga akan mengurangi prosentase sebagai negara konsumen dari berbagai penemuan IPTEK. Hanya perlu membawa RFID tag dan berdiri diatas timbangan kemudian RFID tag di identifikasi oleh sensor RFID, maka nama identitas anak dan hasil berat badan pada timbangan akan secara otomatis ditampilkan di website karena alat akan bekerja sendiri dengan program yang ditentukan [2]. Jadi, dapat dikatakan alat ukur berat badan ini lebih efektif dan efisien dibandingkan dengan pengukuran manual [3].

Berdasarkan observasi dilapangan, penulis ingin mengembangkan sebuah penelitian terdahulu dengan judul "Rancang Bangun Sistem Elektronik Pelaporan Kesehatan Ibu Hamil di Puskesmas Berbasis Online Menggunakan RFID“.

Perbedaan pada penelitian yaitu sasaran penelitian menggunakan balita dan perbedaan fasilitas, rancangan alat yang memiliki fasilitas bisa mengetahui berat badan, tinggi badan, suhu badan, detak jantung secara otomatis ditampilkan di website karena alat akan bekerja sendiri dengan program yang ditentukan. Jadi, dapat dikatakan alat ukur ini lebih efektif dan efisien dibandingkan dengan pengukuran secara manual.

\section{METODE}

\section{A. Tahapan Penelitian}

Rancangan yang akan digunakan dalam penelitian penelitian adalah pembuatan tahap-tahap pencarian informasi, pembuatan alat hingga pengujian, dalam skripsi yang disusun dengan maksud agar penelitian dilakukan secara terperinci dan terencana melalui tahap-tahap yang telah disusun sebelumnya.

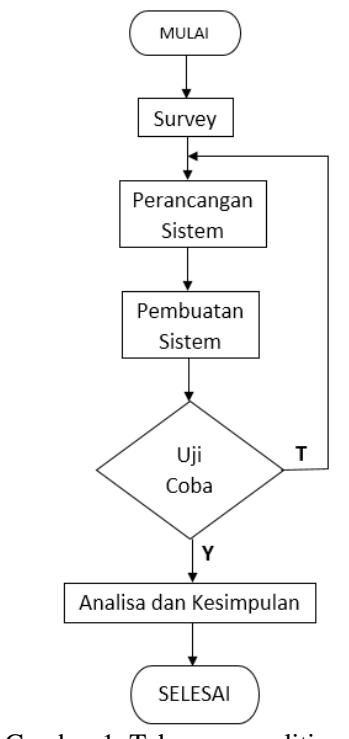

Gambar 1. Tahapan penelitian

- Tahap pertama adalah start studi literatur mengenai NFC , baik itu pengambilan data pada posyandu

- Tahap kedua adalah melakukan survei terhadap kegiatan yang ada di lapangan
- Tahap ketiga adalah perancangan sistem setelah survei, merencana sistem.

- Tahap keempat adalah pembuatan sistem setelah melakukan perancangan, membuat sistem pada alat tersebut.

- Tahap ke lima uji coba sistem, di sini alat di uji agar mengetahui keberhasilanya, jika sistem yang diinginkan sesuai kita bisa melakukan analisa dan kesimpulan. jika sistem tidak sesuai kita akan melakukan survey kembali.

- Tahap keenam adalah analisa dan kesimpulan, setelah di uji kita akan menganalisa dan menyimpulkan dari sistem alat tersebut

\section{B. Perencanaan Sistem}
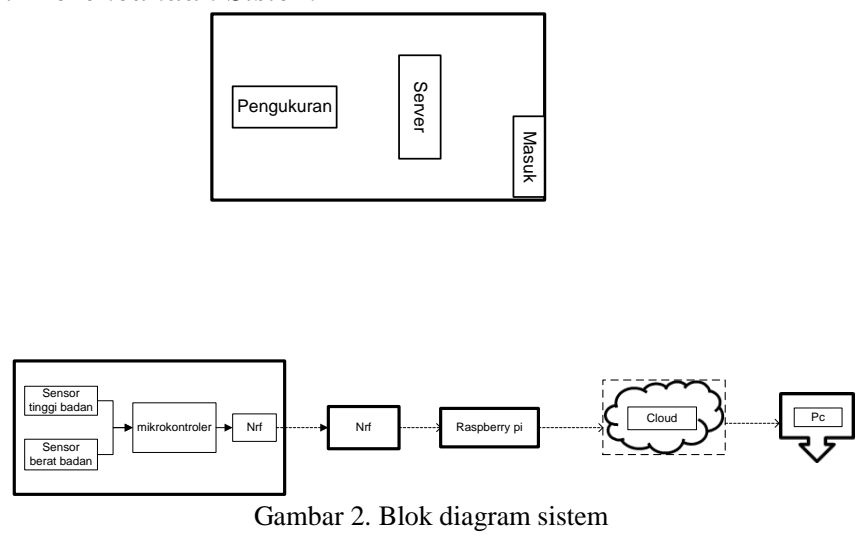

Fungsi mirokontroler adalah untuk menghubungkan seluruh sensor yang di gunakan agar data yang di peroleh dari sensor bisa di kirim ke NRF, kemudian data yang ada pada NRF akan di kirimkan pada raspberry kemudian di simpan pada cloud dan bisa di akses pada web dengan hp atau komputer.

\section{HASIL DAN PEMBAHASAN}

A. Hasil Implementasi Alat

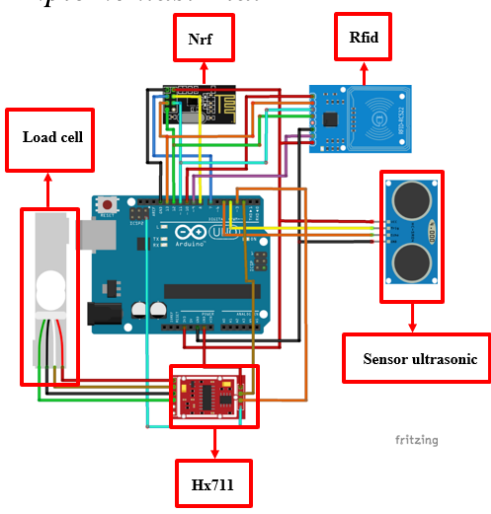

Gambar 3. Implementasi sensor berat dan tinggi 


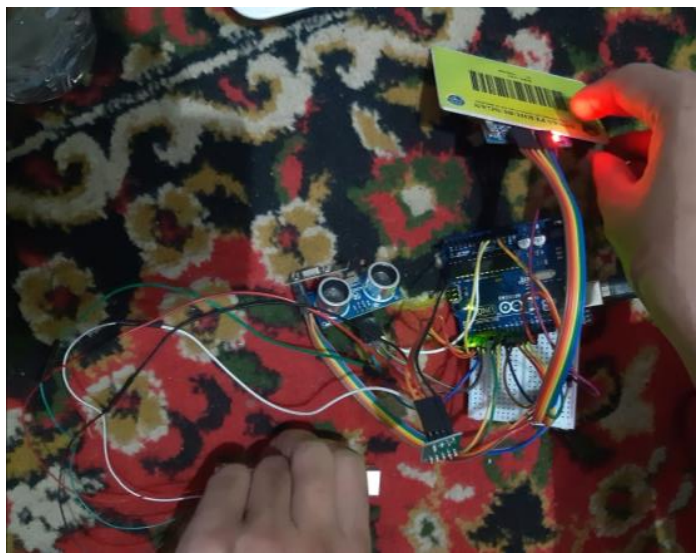

Gambar 4. Hasil implementasi sensor berat dan tinggi (real)

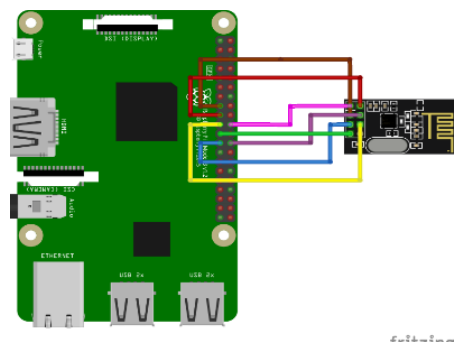

Gambar 5. Implementasi server raspberry

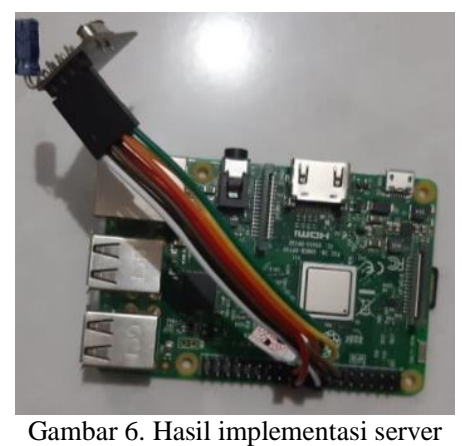

B. Hasil Implementasi Aplikasi Software Web

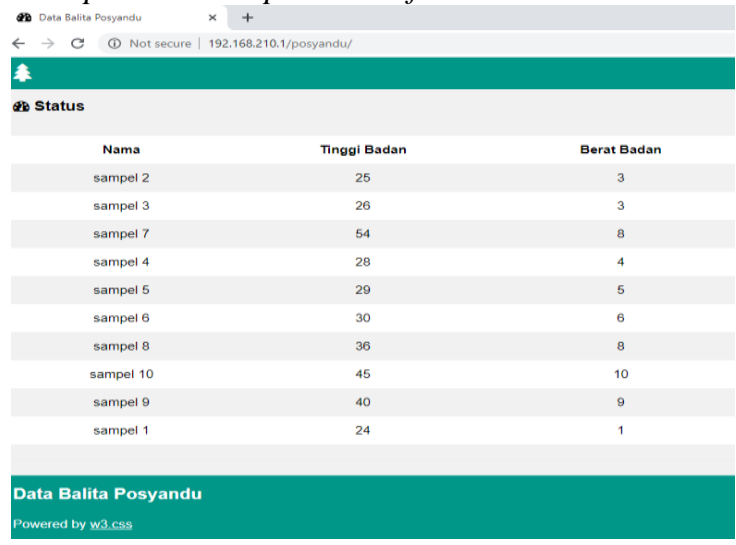

Gambar 7. Tampilan web

Gambar 7 menunjukkan hasil implementasi fitur pada aplikasi web. Pada aplikasi terdapat beberapa tampilan ada nama, data tinggi badan, berat badan, detak jantung, suhu badan.

\section{Hasil Pengujian Alat \\ 1. Pengujian RFID}

TABEL I

HASIL PENGUNJIAN RFID

\begin{tabular}{ccccc}
\hline $\begin{array}{c}\text { Jarak } \\
(\mathbf{c m})\end{array}$ & $\begin{array}{c}\text { Kartu 1 } \\
(\text { detik) }\end{array}$ & $\begin{array}{c}\text { Kartu 2 } \\
(\text { detik})\end{array}$ & $\begin{array}{c}\text { Kartu 3 } \\
(\text { detik })\end{array}$ & Status \\
\hline 0 & 1.1 & 1.3 & 1.1 & terdeteksi \\
\hline 0.5 & 2.1 & 1.8 & 2.3 & terdeteksi \\
\hline 1 & 1.7 & 1.5 & 2.1 & terdeteksi \\
\hline 1.5 & 1.8 & 2.1 & 2.2 & terdeteksi \\
\hline 2 & 2.2 & 2 & 2.5 & terdeteksi \\
\hline 2.5 & 1.8 & 2.3 & 2.8 & terdeteksi \\
\hline 3 & 2.5 & 2.7 & 2.9 & terdeteksi \\
\hline 3.5 & & & & tak terdeteksi \\
\hline 4 & & & & tak terdeteksi \\
\hline 4.5 & & & & tak terdeteksi \\
\hline 5 & & & & tak terdeteksi \\
\hline
\end{tabular}

Pada table 1 dapat di ketahui bahwa pengujian rfid dapat di deteksi pada rentan $0-3 \mathrm{~cm}$ di atas itu kartu tidak bisa terdeteksi.

2. Pengujian sensor load cell

TABEL II

TABEL HASIL SENSOR LOAD CELL

\begin{tabular}{cccccc}
\hline Sample & $\begin{array}{c}\text { Timbangan } \\
\text { Gea }(\mathbf{k g})\end{array}$ & $\begin{array}{c}\text { Sensor } \\
\text { Uji 1 }\end{array}$ & $\begin{array}{c}\text { Sensor } \\
\text { Uji 2 }\end{array}$ & $\begin{array}{c}\text { Sensor } \\
\text { Uji 3 }\end{array}$ & $\begin{array}{c}\text { Persentasi } \\
\text { kesalahan }\end{array}$ \\
\hline Sample 1 & 5 & 5.1 & 5.3 & 5.5 & $6 \%$ \\
\hline Sample 2 & 5,7 & 5.4 & 5.7 & 5.8 & $4.70 \%$ \\
\hline Sample 3 & 5,9 & 5.8 & 5.9 & 6 & $0 \%$ \\
\hline Sample 4 & 6 & 6.1 & 6 & 5.8 & $5 \%$ \\
\hline Sample 5 & 6.3 & 6 & 6.1 & 6.2 & $5.30 \%$ \\
\hline Sample 6 & 6.8 & 6.7 & 6.8 & 7 & $5.70 \%$ \\
\hline Sample 7 & 7 & 7.2 & 7.3 & 7.4 & $5.90 \%$ \\
\hline Sample 8 & 8.5 & 8.3 & 8.4 & 8.5 & $1.10 \%$ \\
\hline Sample 9 & 9 & 8.8 & 9 & 9.1 & $1.10 \%$ \\
\hline Sample 10 & 10 & 9.7 & 9.9 & 10 & $0 \%$ \\
\hline
\end{tabular}

Pada table II dapat diketahui bahwa pengujian sensor loadcell memiliki eror sebesar $1,48 \%$ dan dilakukan pengujian selama 3 kali, agar mengetahui tingkat error. 
Jurnal Jaringan Telekomunikasi, E-ISSN: 2654-6531, P-ISSN: 2407-0807 Vol. 10, No. 4 (2020) 197-201

3. Pengujian sensor ultrasonic (tinggi)

TABEL III

PENGUJIAN SENSOR ULTRASONIC (TINGGI)

\begin{tabular}{cccccc}
\hline Sample & $\begin{array}{c}\text { Alat Ukur } \\
(\mathbf{c m})\end{array}$ & $\begin{array}{c}\text { Sensor } \\
\text { Uji 1 }\end{array}$ & $\begin{array}{c}\text { Sensor } \\
\text { Uji 2 }\end{array}$ & $\begin{array}{c}\text { Sensor } \\
\text { Uji 3 }\end{array}$ & $\begin{array}{c}\text { Persentasi } \\
\text { kesalahan }\end{array}$ \\
\hline Sample 1 & 50 & 51 & 52 & 53 & $0.40 \%$ \\
\hline Sample 2 & 53 & 54 & 52 & 51 & $1.32 \%$ \\
\hline Sample 3 & 56 & 54 & 55 & 57 & $1.25 \%$ \\
\hline Sample 4 & 57 & 58 & 59 & 60 & $3.50 \%$ \\
\hline Sample 5 & 59 & 58 & 60 & 61 & $1.01 \%$ \\
\hline Sample 6 & 60 & 59 & 60 & 61 & $0.00 \%$ \\
\hline Sample 7 & 63 & 64 & 62 & 63 & $0.00 \%$ \\
\hline Sample 8 & 65 & 64 & 66 & 67 & $0.92 \%$ \\
\hline Sample 9 & 68 & 65 & 67 & 69 & $1.47 \%$ \\
\hline Sample 10 & 70 & 69 & 70 & 68 & $1.42 \%$ \\
\hline
\end{tabular}

Pada table III dapat di ketahui bahwa pengujian sensor heart beat memiliki eror sebesar $1,86 \%$ dan dilakukan pengujian selama 3 kali, agar mengetahui tingkat error.

4. Tabel Pengujian Delay Pengiriman Data

TABEL IV

TABEL DELAY

\begin{tabular}{|c|c|c|c|c|c|c|c|}
\hline \multirow[b]{2}{*}{$\begin{array}{c}\text { Ha } \\
\text { ri } \\
\text { ke }\end{array}$} & \multirow[b]{2}{*}{ Waktu } & \multicolumn{6}{|c|}{ Hasil Pengujian Delay } \\
\hline & & $\begin{array}{l}\text { Rou } \\
\text { ter } 1\end{array}$ & $\begin{array}{c}\text { Katego } \\
\text { ri }\end{array}$ & $\begin{array}{l}\text { Rou } \\
\text { ter } 2\end{array}$ & Kategori & $\begin{array}{c}\text { Rou } \\
\text { ter } \\
3\end{array}$ & $\begin{array}{c}\text { Katego } \\
\text { ri }\end{array}$ \\
\hline \multirow{3}{*}{1} & $\begin{array}{c}08.00- \\
09.00\end{array}$ & $\begin{array}{c}0.23 \\
\mathrm{~s}\end{array}$ & Bagus & $\begin{array}{c}0.16 \\
\mathrm{~s}\end{array}$ & Bagus & $\begin{array}{c}0.12 \\
\mathrm{~s}\end{array}$ & Bagus \\
\hline & $\begin{array}{c}12.00- \\
13.00\end{array}$ & $\begin{array}{c}0.26 \\
\mathrm{~s}\end{array}$ & Bagus & $\begin{array}{c}0.17 \\
\mathrm{~s}\end{array}$ & Bagus & 0.19 & Bagus \\
\hline & $\begin{array}{c}16.00- \\
17.00\end{array}$ & $\begin{array}{c}0.18 \\
\mathrm{~s}\end{array}$ & Bagus & $\begin{array}{c}0.18 \\
\mathrm{~s}\end{array}$ & Bagus & $\begin{array}{c}0.21 \\
\mathrm{~s}\end{array}$ & Bagus \\
\hline \multirow{3}{*}{2} & $\begin{array}{c}08.00- \\
09.00\end{array}$ & $\begin{array}{c}0.21 \\
\mathrm{~s}\end{array}$ & Bagus & $\begin{array}{c}0.18 \\
\mathrm{~s}\end{array}$ & Bagus & $\begin{array}{c}0.15 \\
\mathrm{~s}\end{array}$ & Bagus \\
\hline & $\begin{array}{c}12.00- \\
13.00\end{array}$ & $\begin{array}{c}0.14 \\
\mathrm{~s}\end{array}$ & $\begin{array}{l}\text { Sangat } \\
\text { Bagus }\end{array}$ & $\begin{array}{c}0.34 \\
\mathrm{~s}\end{array}$ & Sedang & $\begin{array}{c}0.27 \\
\mathrm{~s}\end{array}$ & Bagus \\
\hline & $\begin{array}{c}16.00- \\
17.00\end{array}$ & $\begin{array}{c}0.12 \\
\mathrm{~s}\end{array}$ & $\begin{array}{l}\text { Sangat } \\
\text { Bagus }\end{array}$ & $\begin{array}{c}0.18 \\
\mathrm{~s}\end{array}$ & $\begin{array}{l}\text { Sangat } \\
\text { Bagus }\end{array}$ & $0.2 \mathrm{~s}$ & Bagus \\
\hline \multirow{3}{*}{3} & $\begin{array}{c}08.00- \\
09.00 \\
\end{array}$ & $0.1 \mathrm{~s}$ & $\begin{array}{l}\text { Sangat } \\
\text { Bagus }\end{array}$ & $\begin{array}{c}0.12 \\
\mathrm{~s} \\
\end{array}$ & $\begin{array}{l}\text { Sangat } \\
\text { Bagus }\end{array}$ & $\begin{array}{c}0.15 \\
\mathrm{~s} \\
\end{array}$ & $\begin{array}{l}\text { Sangat } \\
\text { Bagus }\end{array}$ \\
\hline & $\begin{array}{c}12.00- \\
13.00\end{array}$ & $\begin{array}{c}0.19 \\
\mathrm{~s}\end{array}$ & Bagus & $\begin{array}{c}0.16 \\
\mathrm{~s}\end{array}$ & Bagus & $\begin{array}{c}0.1 . \\
3 \mathrm{~s}\end{array}$ & $\begin{array}{l}\text { Sangat } \\
\text { Bagus }\end{array}$ \\
\hline & $\begin{array}{c}16.00- \\
17.00\end{array}$ & $\begin{array}{c}0.13 \\
\mathrm{~s}\end{array}$ & $\begin{array}{l}\text { Sangat } \\
\text { Bagus }\end{array}$ & $0.2 \mathrm{~s}$ & Bagus & $\begin{array}{c}0.19 \\
\mathrm{~s}\end{array}$ & Bagus \\
\hline \multirow{3}{*}{4} & $\begin{array}{c}08.00- \\
09.00\end{array}$ & $\begin{array}{c}0.18 \\
\mathrm{~s}\end{array}$ & Bagus & $0.3 \mathrm{~s}$ & Sedang & $\begin{array}{c}0.12 \\
\mathrm{~s}\end{array}$ & $\begin{array}{l}\text { Sangat } \\
\text { Bagus }\end{array}$ \\
\hline & $\begin{array}{c}12.00- \\
13.00\end{array}$ & 0.16 & Bagus & $0.4 \mathrm{~s}$ & Sedang & $\begin{array}{c}0.14 \\
\mathrm{~s}\end{array}$ & $\begin{array}{l}\text { Sangat } \\
\text { Bagus }\end{array}$ \\
\hline & $\begin{array}{c}16.00- \\
17.00\end{array}$ & $0.3 \mathrm{~s}$ & Sedang & $\begin{array}{c}0.31 \\
\mathrm{~s}\end{array}$ & Sedang & $\begin{array}{c}0.24 \\
\mathrm{~s}\end{array}$ & Bagus \\
\hline \multirow{2}{*}{5} & $\begin{array}{c}08.00- \\
09.00\end{array}$ & $\begin{array}{c}0.16 \\
\mathrm{~s}\end{array}$ & Bagus & $0.3 \mathrm{~s}$ & Sedang & $\begin{array}{c}0.12 \\
\mathrm{~s}\end{array}$ & $\begin{array}{l}\text { Sangat } \\
\text { Bagus }\end{array}$ \\
\hline & $\begin{array}{c}12.00- \\
13.00\end{array}$ & $\begin{array}{c}0.16 \\
\mathrm{~s}\end{array}$ & Bagus & $0.4 \mathrm{~s}$ & Sedang & $\begin{array}{c}0.11 \\
\mathrm{~s}\end{array}$ & $\begin{array}{c}\text { Sangat } \\
\text { Bagus }\end{array}$ \\
\hline
\end{tabular}

\begin{tabular}{|c|c|c|c|c|c|c|c|}
\hline & $\begin{array}{c}16.00- \\
17.00\end{array}$ & $0.1 \mathrm{~s}$ & $\begin{array}{l}\text { Sangat } \\
\text { Bagus }\end{array}$ & $0.2 \mathrm{~s}$ & Bagus & $\begin{array}{c}0.23 \\
\mathrm{~s}\end{array}$ & Bagus \\
\hline \multirow{3}{*}{6} & $\begin{array}{c}08.00- \\
09.00\end{array}$ & $\begin{array}{c}0.18 \\
\mathrm{~s}\end{array}$ & Bagus & $0.3 \mathrm{~s}$ & Sedang & $\begin{array}{c}0.12 \\
\mathrm{~s}\end{array}$ & $\begin{array}{l}\text { Sangat } \\
\text { Bagus }\end{array}$ \\
\hline & $\begin{array}{c}12.00- \\
13.00\end{array}$ & $\begin{array}{c}0.16 \\
\mathrm{~s}\end{array}$ & Bagus & $0.4 \mathrm{~s}$ & Sedang & $\begin{array}{c}0.13 \\
\mathrm{~s}\end{array}$ & $\begin{array}{l}\text { Sangat } \\
\text { Bagus }\end{array}$ \\
\hline & $\begin{array}{c}16.00- \\
17.00\end{array}$ & $0.2 \mathrm{~s}$ & Bagus & $\begin{array}{c}0.27 \\
\mathrm{~s}\end{array}$ & Bagus & $\begin{array}{c}0.24 \\
\mathrm{~s}\end{array}$ & Bagus \\
\hline \multirow{3}{*}{7} & $\begin{array}{c}08.00- \\
09.00\end{array}$ & $\begin{array}{c}0.18 \\
\mathrm{~s}\end{array}$ & Bagus & $\begin{array}{c}0.31 \\
\mathrm{~s}\end{array}$ & Sedang & $\begin{array}{c}0.12 \\
\mathrm{~s}\end{array}$ & $\begin{array}{l}\text { Sangat } \\
\text { Bagus }\end{array}$ \\
\hline & $\begin{array}{c}12.00- \\
13.00\end{array}$ & $\begin{array}{c}0.16 \\
\mathrm{~s}\end{array}$ & Bagus & $\begin{array}{c}0.41 \\
\mathrm{~s}\end{array}$ & Sedang & $\begin{array}{c}0.14 \\
\mathrm{~s}\end{array}$ & $\begin{array}{l}\text { Sangat } \\
\text { Bagus }\end{array}$ \\
\hline & $\begin{array}{c}16.00- \\
17.00\end{array}$ & $0.3 \mathrm{~s}$ & Bagus & $0.2 \mathrm{~s}$ & Bagus & $\begin{array}{c}0.27 \\
\mathrm{~s}\end{array}$ & Bagus \\
\hline
\end{tabular}

Berdasarkan hasil pengujian di atas, pada tabel IV dapat diketahui bahwa nilai delay pada router 1 pada jam 08.00 09.00 dari hari 1-7 yang memiliki hasil pengukuran yang presisi dengan nilai patokan di hari ke 3 dengan nilai $0,1 \mathrm{~s}$. Lalu untuk router 2 pada jam 08.00 - 09.00 dari hari 1-7 yang memiliki hasil pengukuran yang presisi dengan nilai patokan di hari ke 4,5,6 dengan nilai 0,3s. router 3 pada jam 08.00 09.00 dari hari 1-7 yang memiliki hasil pengukuran yang presisi dengan nilai patokan di hari ke 1,4,6,7 dengan nilai $0,12 \mathrm{~s}$.

Pada router 1 pada jam 12.00 - 13.00 dari hari 1-7 yang memiliki hasil pengukuran yang presisi dengan nilai patokan di hari ke 2 dengan nilai $0,14 \mathrm{~s}$. Lalu untuk router 2 pada jam 12.00 - 13.00 dari hari 1-7 yang memiliki hasil pengukuran yang presisi dengan nilai patokan di hari ke 3,4,5 dengan nilai 0,4 s. router 3 pada jam 12.00 - 13.00 dari hari 1-7 yang memiliki hasil pengukuran yang presisi dengan nilai patokan di hari ke 4 dengan nilai $0,11 \mathrm{~s}$.

Pada router 1 pada jam 16.00 - 17.00 dari hari 1-7 yang memiliki hasil pengukuran yang presisi dengan nilai patokan di hari ke 5 dengan nilai $0,1 \mathrm{~s}$. Lalu untuk router 2 pada jam 16.00 - 17.00 dari hari 1-7 yang memiliki hasil pengukuran yang presisi dengan nilai patokan di hari ke 3,5,7 dengan nilai 0,2 s. router 3 pada jam 16.00 - 17.00 dari hari 1-7 yang memiliki hasil pengukuran yang presisi dengan nilai patokan di hari ke 2 dengan nilai 0,2 s.

Dari hasil delay di atas memiliki nilai terbaik pada pukul 16.00 - 17.00 adalah hari ke 5 dengan nilai 0,1 second menggunakan router 1 , kemudian dapat diketahui bahwa nilai delay terburuk pada pukul $12.00-13.00$ adalah hari ke 7 dengan niai 4,1 second menggunakan router 2 . 
5. Tabel Pengujian packet Loss Pengiriman Data

TABEL IV

PENGUJian PACKet Loss PENGIRIMAN DATA

\begin{tabular}{|c|c|c|c|c|c|c|c|}
\hline \multirow{2}{*}{$\begin{array}{c}\text { Ha } \\
\text { ri } \\
\text { ke }\end{array}$} & \multirow[b]{2}{*}{ Waktu } & \multicolumn{6}{|c|}{ Hasil Pengujian Packet Loss } \\
\hline & & $\begin{array}{l}\text { Rou } \\
\text { ter } 1\end{array}$ & $\begin{array}{c}\text { Katego } \\
\text { ri }\end{array}$ & $\begin{array}{l}\text { Rou } \\
\text { ter } 2\end{array}$ & $\begin{array}{c}\text { Katego } \\
\text { ri }\end{array}$ & $\begin{array}{l}\text { Rou } \\
\text { ter } 3\end{array}$ & $\begin{array}{c}\text { Katego } \\
\text { ri }\end{array}$ \\
\hline \multirow{3}{*}{1} & $\begin{array}{c}08.00- \\
09.00\end{array}$ & $0 \%$ & $\begin{array}{l}\text { Sangat } \\
\text { Bagus }\end{array}$ & $\begin{array}{c}0.07 \\
\%\end{array}$ & $\begin{array}{l}\text { Sangat } \\
\text { Bagus }\end{array}$ & $\begin{array}{c}0.18 \\
\%\end{array}$ & $\begin{array}{l}\text { Sangat } \\
\text { Bagus }\end{array}$ \\
\hline & $\begin{array}{c}12.00- \\
13.00\end{array}$ & $\begin{array}{c}0.02 \\
\%\end{array}$ & $\begin{array}{l}\text { Sangat } \\
\text { Bagus }\end{array}$ & $\begin{array}{c}0.09 \\
\%\end{array}$ & $\begin{array}{l}\text { Sangat } \\
\text { Bagus }\end{array}$ & $\begin{array}{c}0.05 \\
\%\end{array}$ & $\begin{array}{l}\text { Sangat } \\
\text { Bagus }\end{array}$ \\
\hline & $\begin{array}{c}16.00- \\
17.00\end{array}$ & $\begin{array}{c}0.10 \\
\%\end{array}$ & $\begin{array}{l}\text { Sangat } \\
\text { Bagus }\end{array}$ & $0 \%$ & $\begin{array}{l}\text { Sangat } \\
\text { Bagus }\end{array}$ & $\begin{array}{c}0.13 \\
\%\end{array}$ & $\begin{array}{l}\text { Sangat } \\
\text { Bagus }\end{array}$ \\
\hline \multirow{3}{*}{2} & $\begin{array}{c}08.00- \\
09.00\end{array}$ & $0 \%$ & $\begin{array}{l}\text { Sangat } \\
\text { Bagus }\end{array}$ & $0 \%$ & $\begin{array}{l}\text { Sangat } \\
\text { Bagus }\end{array}$ & $0 \%$ & $\begin{array}{l}\text { Sangat } \\
\text { Bagus }\end{array}$ \\
\hline & $\begin{array}{c}12.00- \\
13.00\end{array}$ & $0 \%$ & $\begin{array}{l}\text { Sangat } \\
\text { Bagus }\end{array}$ & $0 \%$ & $\begin{array}{l}\text { Sangat } \\
\text { Bagus }\end{array}$ & $\begin{array}{c}0.13 \\
\% \\
\end{array}$ & $\begin{array}{l}\text { Sangat } \\
\text { Bagus }\end{array}$ \\
\hline & $\begin{array}{c}16.00- \\
17.00\end{array}$ & $\begin{array}{c}0.10 \\
\%\end{array}$ & $\begin{array}{l}\text { Sangat } \\
\text { Bagus }\end{array}$ & $\begin{array}{c}0.07 \\
\%\end{array}$ & $\begin{array}{l}\text { Sangat } \\
\text { Bagus }\end{array}$ & $\begin{array}{c}0.20 \\
\%\end{array}$ & $\begin{array}{l}\text { Sangat } \\
\text { Bagus }\end{array}$ \\
\hline \multirow{3}{*}{3} & $\begin{array}{c}08.00- \\
09.00\end{array}$ & $\begin{array}{c}0.02 \\
\%\end{array}$ & $\begin{array}{l}\text { Sangat } \\
\text { Bagus }\end{array}$ & $\begin{array}{c}0.05 \\
\%\end{array}$ & $\begin{array}{l}\text { Sangat } \\
\text { Bagus }\end{array}$ & $\begin{array}{c}0.11 \\
\%\end{array}$ & $\begin{array}{l}\text { Sangat } \\
\text { Bagus }\end{array}$ \\
\hline & $\begin{array}{c}12.00- \\
13.00\end{array}$ & $\begin{array}{c}0.20 \\
\%\end{array}$ & $\begin{array}{l}\text { Sangat } \\
\text { Bagus }\end{array}$ & $\begin{array}{c}0.04 \\
\%\end{array}$ & $\begin{array}{l}\text { Sangat } \\
\text { Bagus }\end{array}$ & $0 \%$ & $\begin{array}{l}\text { Sangat } \\
\text { Bagus }\end{array}$ \\
\hline & $\begin{array}{c}16.00- \\
17.00\end{array}$ & $\begin{array}{c}0.19 \\
\%\end{array}$ & $\begin{array}{l}\text { Sangat } \\
\text { Bagus }\end{array}$ & $\begin{array}{c}0.00 \\
8 \%\end{array}$ & $\begin{array}{l}\text { Sangat } \\
\text { Bagus }\end{array}$ & $\begin{array}{c}0.18 \\
\%\end{array}$ & $\begin{array}{l}\text { Sangat } \\
\text { Bagus }\end{array}$ \\
\hline \multirow{3}{*}{4} & $\begin{array}{c}08.00- \\
09.00\end{array}$ & $\begin{array}{c}0.05 \\
\%\end{array}$ & $\begin{array}{l}\text { Sangat } \\
\text { Bagus }\end{array}$ & $\begin{array}{c}0.01 \\
\%\end{array}$ & $\begin{array}{l}\text { Sangat } \\
\text { Bagus }\end{array}$ & $\begin{array}{c}0.02 \\
\%\end{array}$ & $\begin{array}{l}\text { Sangat } \\
\text { Bagus }\end{array}$ \\
\hline & $\begin{array}{c}12.00- \\
13.00\end{array}$ & $0 \%$ & $\begin{array}{l}\text { Sangat } \\
\text { Bagus }\end{array}$ & $\begin{array}{c}0.07 \\
\%\end{array}$ & $\begin{array}{l}\text { Sangat } \\
\text { Bagus }\end{array}$ & $\begin{array}{c}0.06 \\
\%\end{array}$ & $\begin{array}{l}\text { Sangat } \\
\text { Bagus }\end{array}$ \\
\hline & $\begin{array}{c}16.00- \\
17.00\end{array}$ & $\begin{array}{c}0.07 \\
\%\end{array}$ & $\begin{array}{l}\text { Sangat } \\
\text { Bagus }\end{array}$ & $\begin{array}{c}0.02 \\
\%\end{array}$ & $\begin{array}{l}\text { Sangat } \\
\text { Bagus }\end{array}$ & $\begin{array}{c}0.02 \\
\%\end{array}$ & $\begin{array}{l}\text { Sangat } \\
\text { Bagus }\end{array}$ \\
\hline \multirow{3}{*}{5} & $\begin{array}{c}08.00- \\
09.00\end{array}$ & $\begin{array}{c}0.05 \\
\%\end{array}$ & $\begin{array}{l}\text { Sangat } \\
\text { Bagus }\end{array}$ & $\begin{array}{c}0.01 \\
\%\end{array}$ & $\begin{array}{l}\text { Sangat } \\
\text { Bagus }\end{array}$ & $0 \%$ & $\begin{array}{l}\text { Sangat } \\
\text { Bagus }\end{array}$ \\
\hline & $\begin{array}{c}12.00- \\
13.00\end{array}$ & $\begin{array}{c}0.03 \\
\%\end{array}$ & $\begin{array}{l}\text { Sangat } \\
\text { Bagus }\end{array}$ & $\begin{array}{c}0.02 \\
\%\end{array}$ & $\begin{array}{l}\text { Sangat } \\
\text { Bagus }\end{array}$ & $\begin{array}{c}0.01 \\
\%\end{array}$ & $\begin{array}{l}\text { Sangat } \\
\text { Bagus }\end{array}$ \\
\hline & $\begin{array}{c}16.00- \\
17.00 \\
\end{array}$ & $\begin{array}{c}0.08 \\
\%\end{array}$ & $\begin{array}{l}\text { Sangat } \\
\text { Bagus }\end{array}$ & $\begin{array}{c}0.02 \\
\% \\
\end{array}$ & $\begin{array}{l}\text { Sangat } \\
\text { Bagus }\end{array}$ & $\begin{array}{c}0.02 \\
\%\end{array}$ & $\begin{array}{l}\text { Sangat } \\
\text { Bagus }\end{array}$ \\
\hline \multirow{3}{*}{6} & $\begin{array}{c}08.00- \\
09.00\end{array}$ & $\begin{array}{c}0.02 \\
\%\end{array}$ & $\begin{array}{l}\text { Sangat } \\
\text { Bagus }\end{array}$ & $\begin{array}{c}0.01 \\
\%\end{array}$ & $\begin{array}{l}\text { Sangat } \\
\text { Bagus }\end{array}$ & $\begin{array}{c}0.03 \\
\%\end{array}$ & $\begin{array}{l}\text { Sangat } \\
\text { Bagus }\end{array}$ \\
\hline & $\begin{array}{c}12.00- \\
13.00\end{array}$ & $\begin{array}{c}0.10 \\
\%\end{array}$ & $\begin{array}{l}\text { Sangat } \\
\text { Bagus }\end{array}$ & $\begin{array}{c}0.02 \\
\%\end{array}$ & $\begin{array}{l}\text { Sangat } \\
\text { Bagus }\end{array}$ & $\begin{array}{c}0.03 \\
\%\end{array}$ & $\begin{array}{l}\text { Sangat } \\
\text { Bagus }\end{array}$ \\
\hline & $\begin{array}{c}16.00- \\
17.00\end{array}$ & $\begin{array}{c}0.09 \\
\%\end{array}$ & $\begin{array}{l}\text { Sangat } \\
\text { Bagus }\end{array}$ & $\begin{array}{c}0.01 \\
\%\end{array}$ & $\begin{array}{l}\text { Sangat } \\
\text { Bagus }\end{array}$ & $\begin{array}{c}0.10 \\
\%\end{array}$ & $\begin{array}{l}\text { Sangat } \\
\text { Bagus }\end{array}$ \\
\hline \multirow{3}{*}{7} & $\begin{array}{c}08.00- \\
09.00\end{array}$ & $\begin{array}{c}0.04 \\
\%\end{array}$ & $\begin{array}{l}\text { Sangat } \\
\text { Bagus }\end{array}$ & $\begin{array}{c}0.02 \\
\%\end{array}$ & $\begin{array}{l}\text { Sangat } \\
\text { Bagus }\end{array}$ & $0 \%$ & $\begin{array}{l}\text { Sangat } \\
\text { Bagus }\end{array}$ \\
\hline & $\begin{array}{c}12.00- \\
13.00\end{array}$ & $\begin{array}{c}0.30 \\
\%\end{array}$ & $\begin{array}{l}\text { Sangat } \\
\text { Bagus }\end{array}$ & $\begin{array}{c}0.04 \\
\%\end{array}$ & $\begin{array}{l}\text { Sangat } \\
\text { Bagus }\end{array}$ & $\begin{array}{c}0.08 \\
\%\end{array}$ & $\begin{array}{l}\text { Sangat } \\
\text { Bagus }\end{array}$ \\
\hline & $\begin{array}{c}16.00- \\
17.00\end{array}$ & $\begin{array}{c}0.08 \\
\%\end{array}$ & $\begin{array}{l}\text { Sangat } \\
\text { Bagus }\end{array}$ & $\begin{array}{c}0.03 \\
\%\end{array}$ & $\begin{array}{l}\text { Sangat } \\
\text { Bagus }\end{array}$ & $\begin{array}{c}0.30 \\
\%\end{array}$ & $\begin{array}{l}\text { Sangat } \\
\text { Bagus }\end{array}$ \\
\hline
\end{tabular}

Berdasarkan hasil pengujian di atas, dapat diketahui bahwa nilai packet loss pada router 1 pada jam $08.00-09.00$ dari hari 1-7 yang memiliki hasil pengukuran yang presisi dengan nilai patokan di hari ke 1,2 dengan nilai $0 \mathrm{~s}$. Lalu untuk router 2 pada jam 08.00 - 09.00 dari hari 1-7 yang memiliki hasil pengukuran yang presisi dengan nilai patokan di hari ke 2 dengan nilai $0 \mathrm{~s}$. Router 3 pada jam 08.00 - 09.00 dari hari 1-7 yang memiliki hasil pengukuran yang presisi dengan nilai patokan di hari ke 2,4,5,7 dengan nilai $0 \mathrm{~s}$.

Pada router 1 pada jam 12.00 - 13.00 dari hari 1-7 yang memiliki hasil pengukuran yang presisi dengan nilai patokan di hari ke 2 dengan nilai 0 s.lalu untuk router 2 pada jam 12.00 - 13.00 dari hari 1-7 yang memiliki hasil pengukuran yang presisi dengan nilai patokan di hari ke 2 dengan nilai $0 \mathrm{~s}$. router 3 pada jam 12.00 - 13.00 dari hari 1-7 yang memiliki hasil pengukuran yang presisi dengan nilai patokan di hari ke 2 dengan nilai $0 \mathrm{~s}$

Pada router 1 pada jam 16.00 - 17.00 dari hari 1-7 yang memiliki hasil pengukuran yang presisi dengan nilai patokan di hari ke 1,2 dengan nilai 0,1 s.lalu untuk router 2 pada jam 16.00 - 17.00 dari hari 1-7 yang memiliki hasil pengukuran yang presisi dengan nilai patokan di hari ke 1 dengan nilai $0 \mathrm{~s}$. router 3 pada jam 16.00 - 17.00 dari hari 1-7 yang memiliki hasil pengukuran yang presisi dengan nilai patokan di hari ke 6 dengan nilai $0,1 \mathrm{~s}$.

Dari penelitian di atas yang memiliki nilai packet loss terbaik pada pukul 08.00 - 09.00 adalah hari ke 2 dengan nilai $0 \%$, kemudian packet loss terburuk pada pukul $08.00-09.00$ adalah hari ke 1 dengan nilai $0,18 \%$ menggunakan router .

\section{KESIMPULAN}

1. Dalam merancang sistem E- rekam medis yang di buat pada posyandu sesuai dengan yang di rencanakan dimana sistem dapat mengukur berat badan menggunakan sensor load cell dan sensor ultrasonic untuk pendeteksian tinggi badan pada batita yang diukur dengan rata rata presentase kesalahan deteksi sensor load cell sebesar 3,48\% dan presentase kesalahan deteksi sensor ultrasonic sebesar $1,129 \%$.

2. Aplikasi E-rekam medis yang dibuat dapat menampilkan data batita posyandu meliputi nama batita, tinggi dan berat badan sesuai yang di rencanakan.

3. Pengujian Quality of Service (QOS) berdasarkan standar TIPHON di dapatkan nilai packet loss kategori baik dengan nilai $0 \%$, kemudian nilai packet loss kategori jelek dengan nilai $0,18 \%$. Untuk hasil delay didapatkan nilai delay kategori baik dengan nilai 0,1 second dan nilai delay kategori jelek dengan nilai 4,1second.

\section{REFERENSI}

[1] Nurhidayah Listia, "Faktor - Faktor yang Berhubungan dengan Pemanfaatan Puskesmas", Jurnal Mahasiswa Universitas Muhammadiyah Purwokerto, 2017

[2] "Pemanfaatan Teknologi RFID (Radio Frequency Identification) dalam Layanan Registrasi Rekam Medis Pasien”, Teknik Elektromedik Semarang, 2016

[3] Muhammad Afdali, Muhammad Daud, Raihan Putri. "Perancangan Alat Ukur Digital untuk Tinggi dan Berat Badan dengan Output Suara berbasis Arduino UNO" Jurusan Teknik Elektro, FakultasTeknik, Universitas Malikussaleh 